\title{
PENTINGNYA MEMAHAMI TUJUAN DAN KRITERIA PERENCANAAN ASUHAN KEPERAWATAN \\ Dwi Syafriningsih
}

\section{Email : dwisyafriningsih@gmail.com}

\section{LATAR BELAKANG}

Perencanaan keperawatan merupakan suatu proses di dalam pemecahan masalah yang merupakan keputusan awal tentang sesuatu yang akan dilakukan, bagaimana dilakukan, kapan dilakukan, siapa yang melakukan dari semua tindakan keperawatan (Dermawan, 2012).

Perawat harus membuat rencana tindakan keperawatan untuk mengatasi masalah dan juga untuk meningkatkan kesehatan dan keselamatan pasien. Perencanaan keperawatan merupakan suatu rancangan kegiatan untuk penentuan langkah-langkah pemecahan masalah dan prioritasnya, perumusan tujuan, rencana tindakan dan penilaian asuhan keperawatan pada pasien/klien berdasarkan analisis data dan diagnosa keperawatan.

Perencanaan Keperawatan merupakan suatu proses penyusunan dari berbagai intervensi keperawatan yang dibutuhkan untuk mencegah, menurunkan, atau mengurangi masalah-masalah klien. Perencanaan keperawatan ini merupakan langkah ketiga dalam membuat suatu proses keperawatan. Dalam menentukan rencana tindakan terdapat beberapa instruksi tindakan keperawatan yang merupakan suatu bentuk dari tindakan yang menunjukan perawatan dan pengobatan khusus, dimana perawat mempunyai kewenangan untuk melakukan tindakan pada pasien tertentu. Perawatan dan pengobatan dirancang untuk membantu pencapaian satu atau lebih dari tujuan perawatan sehingga dapat mengurangi, mencegah atau menghilangkan dari masalah pasien. (A. Aziz Alimul Hidayat, pengantar konsep dasar keperawatan).

Menurut Undang-Undang Rebuplik Indonesia Nomor 38 Tahun 2014 tentang keperawatan, keperawatan adalah pemberi asuhan kepada individu, keluarga, kelompok, atau masyarakat, baik dalam keadaan sakit maupun sehat (Pemerintah Republik Indonesia,2014). 


\section{METODE}

Metode dalam penulisan ini menggunakan metode kualitatif, yaitu merupakan metode yang sifatnya memberikan suatu penjelasan dengan analisis. Metode ini bersifat subjektif, yaitu proses penelitian yang lebih fokus pada landasan teori. Metode yang digunakan dalam kajian ini adalah Literature review. Metode ini menganalisis, eksplorasi dan kajian bebas pada artikel, jurnal, maupun ebook yang releven dan berfokus pada metode pembelajaran yang mempengaruhi kemampuan mahasiswa agar mampu memahami tujuan dan juga kriteria dalam perencanaan keperawatan. Adapun artikel yang digunakan pada literature review ini adalah artikel yang didapatkan dengan memuat 3 database Pubmed, Geogle Scholar dan Science Direct.

\section{HASIL}

Berdasarkan hasil pencarian literature didapatkan bahwa perencanaan keperawatan belum sepenuhnya dapat dipahami atau dapat dilakukan dengan baik oleh perawat. Dalam melakukan tindakan sesuai dengan rencana keperawatan maka diperlukan jumlah tenaga perawat yang cukup, pengetahuan dan keterampilan yang baik. Tenaga perawat yang paling dibutuhkan ketika jumlah klien meningkat dan kondisi klien menurun (Potter \& Perry, 2005).

Rencana keperawatan adalah suatu metode komunikasi mengenai asuhan keperawatan kepada pasien (Aziz, 2002). Setiap pasien yang memerlukan asuhan keperawatan perlu suatu perencanaan yang baik. Perencanaan merupakan bagian dari fase pengorganisasian dalam proses keperawatan yang meliputi tujuan perawatan, penetapan pemecahan masalah, dan menentukan tujuan perencanaan untuk mengatasi masalah klien (Aziz, 2002). Suatu perencanaan yang kurang baik akan berakibat rendahnya mutu pelayanan keperawatan pada pasien sebagai akibat dari data yang kurang lengkap.

Tujuan rencana asuhan keperawatan yaitu tujuan administrasi meliputi mengidentifikasi fokus keperawatan individu atau keluarga, membedakan tanggung jawab perawat dengan profesi kesehatan lainnya, menyusun kriteria guna pengulangan asuhan keperawatan dan evaluasi, keberhasilan asuhan keperawatan, menyediakan kriteria klasifikasi klien, sedangkan tujuan klinik meliputi suatu pedoman dalam penulisan, mengkomunikasikan asuhan keperawatan yang akan diimplememtasikan dengan perawat lain seperti apa yang akan diajarkan, 
apa yang harus diobservasi, apa yang akan dilakukan.

Menyusun kriteria hasil (outcome) untuk pengulangan asuhan keperawatan dan evaluasi keberhasilan asuhan keperawatan, rencana intervensi yang spesifik dan langsung bagi perawat untuk melaksanakan intervensi kepada klien dan keluarganya (Cafenito,2006).

\section{PEMBAHASAN}

Perencanaan keperawatan merupakan rencana tindakan keperawatan tertulis yang menggambarkan masalah kesehatan pasien, hasil yang akan diharapkan, tindakan-tindakan keperawatan dan kemajuan pasien secara spesifik (Manurung, 2011).

Tujuan perencanaan keperawatan dan aktivitas keperawatan untuk mengurangi, menghilangkan, dan mencegah masalah keperawatan klien. Kriteria proses perawatan membuat rencana tindakan asuhan keperawatan untuk mengatasi masalah dan meningkatkan kesehatan meliputi perencanaan terdiri atas prioritas, tujuan dan rencana tindakan keperawatan, bekerjasama dengan klien dalam menyusun rencana tindakan keperawatan, perencanaan bersifat individual sesuai dengan kondisi atau kebutuhan klien, mendokumentasikan rencana keperawatan (Nursalam,2007).
Tujuan rencana tindakan dibagi menjadi dua menurut Dermawan (2012) yaitu:

a) Tujuan administratif

(1) Untuk mengidentifikasi fokus keperawatan kepada pasien atau kelompok.

(2) Untuk membedakan tanggungjawab perawat dengan profesi kesehatan lainnya.

(3) Untuk menyediakan suatu kriteria guna pengulangan dan evaluasi keperawatan.

(4) Untuk menyediakan kriteria klasifikasi pasien.

b) Tujuan klinik

(1) Menyediakan suatu pedoman dalam penulisan.

(2) Mengkomunikasikan dengan staf perawat; apa yang diajarkan, diobservasi dan dilaksanakan.

(3) Rencana tindakan yang spesifik secara langsung bagi individu, keluarga, dan tenaga kesehatan lainnya untuk melaksanakan tindakan.

Pada proses perencanaan keperawatan, perawat jarang mengalami kesulitan. Hal ini terjadi dikarenakan proses perencanaan sudah mengacu pada panduan yang sudah tersedia di tiap rumah sakit. Panduan tersebut berupa lembar intervensi keperawatan berdasarkan tiap diagnosa keperawatan yang telah ditentukan.

Perencanaan keperawatan disusun berdasarkan diagnosa keperawatan . Komponen perencanaan keperawatan meliputi (Nursalam, 2012) : 
a. Prioritas masalah dengan kriteria : masalahmasalah yang mengancam kehidupan merupakan prioritas pertama., masalah-masalah yang mengancam kesehatan seseorang adalah prioritas kedua, masalah-masalah yang mempengaruhi perilaku merupakan prioritas ketiga.

b. Tujuan asuhan keperawatan dengan kriteria : spesifik, bisa diukur, bisa dicapai, realistik, ada batas waktu.

c. Rencana tindakan dengan kriteria : disusun berdasarkan tujuan asuhan keperawatan, melibatkan pasien/keluarga, mempertimbangkan latar belakang budaya pasien/keluarga, menentukan alternative tindakan yang tepat, mempertimbangkan kebijaksanaan dan peraturan yang berlaku, lingkungan, sumberdaya dan fasilitas yang ada, menjamin rasa aman dan nyaman bagi pasien, kalimat instruksi, ringkas, tegas dengan bahasanya mudah dimengerti.

Karakteristik rencana tindakan keperawatan:

a. Konsisten dengan rencana tindakan.

b. Berdasarkan prinsip-prinsip ilmiah(rasional).

c. Berdasarkan situasi individu klien.

d. Digunakan untuk menciptakan suatu situasi yang aman dan teraupetik.

e. Menciptakan suatu situasi pengajaran.

f. Menunggu saran yang sesuai(ANA,1973).

Perencanaan keperawatan disusun berdasarkan diagnosa keperawatan yang meliputi beberapa point seperti :
A. Prioritas asuhan keperawatan dengan kriteria : Spesifik, bisa diukur, bisa dicapai,realistik, ada batas waktu.

B. Tujuan asuhan keperawatan dengan kriteria : spesifik, bisa diukur, bisa dicapai, realistik,ada batas waktu.

C. Rencana tindakan dengan kriteria yang disusun berdasarkan tujuan asuhan keperawatan, melibatkan pasien/keluarga, mempertimbangkan latar belakang budaya pasien/keluarga,menentukan alternative tindakan yang tepat, mempertimbangkan kebijaksaandan peraturan yang berlaku, lingkungan, sumberdaya, dan fasilitas yang ada, menjamin rasa aman dan nyaman bagi pasien, kalimat intruksi, ringkas, tegas dengan bahasanya mudah dimengerti.

\section{PENUTUP}

\section{KESIMPULAN}

Perencanaan Keperawatan merupakan suatu proses penyusunan dari berbagai intervensi keperawatan yang dibutuhkan untuk mencegah, menurunkan, atau mengurangi masalah-masalah klien. Perencanaan keperawatan ini merupakan langkah ketiga dalam membuat suatu proses keperawatan. Tujuan perencanaan keperawatan dan aktivitas keperawatan untuk mengurangi, menghilangkan, dan mencegah masalah keperawatan klien. Kriteria proses perawatan membuat rencana tindakan 
asuhan keperawatan untuk mengatasi masalah dan meningkatkan kesehatan.

\section{SARAN}

Mengingat pentingnya perencanaan keperawatan maka dianjurkan atau disarankan kepada perawat untuk memahami dan juga mengetahui tujuan dan kriteria dari perencanaan asuhan keperawatan agar pengetahun tentang asuhan keperawatan semakin baik dan juga meningkat terlebih pada perencanaan keperawatan itu sendiri.

\section{DAFTAR PUSTAKA}

Butar-Butar, J., \& Simamora, R. H. (2016). Hubungan Mutu Pelayanan Keperawatan dengan Tingkat Kepuasan Pasien Rawat Inap di RSUD Pandan Kabupaten Tapanuli Tengah. Jurnal Ners Indonesia, 6(1), 50-63.

Carpenito, L.J., (1999). Rencana Asuhan dan Dokumentasi Keperawatan, Diagnosa Keperawatan dan Masalah Kolaboratif Edisi 2. Jakarta: EGC.

Dermawan,D. (2012). Proses Keperawatan Penerapan Konsep dan Kerangka Kerja (1st ed.). Yogyakarta: Gosyen Publishing

Doengos, M.E., (2000), Rencana Asuhan Keperawatan : Pedoman Untuk
Perencanaan Pendokumentasian Perawatan Pasien Ed. 3

Efendi, N. F. (2015). Pendidikan dalam keperawatan. Surabaya: Salemba Medika

Kozier, Barbara. (2010). Buku Ajar Fundamental Keperawatan; Konsep, Proses dan Praktik edisi 7 Volume. Jakarta: EGC.

Mulyanti, D.Y. (2017). Bahan Ajar Keperawatan Dokumentasi Keperawatan. Jakarta: EGC.

Muryani. (2019). Upaya Optimalisasi Penerapan Metode Asuhan Keperawatan Profesional (MAKP) Model Tim dalam Meningkatkan Kinerja Perawat di Ruang Rawat Inap Rumah Sakit Muhammadiyah BABAT. Tesis. Universitas Airlangga Fakultas Kesehatan Masyarakat Program Magister Program Studi Administrasi dan Kebijakan Kesehatan.

Nursalam.2016. Manajemen Keperawatan Aplikasi Dalam Praktek Keperawatan Profesional. 5 ed. Jakarta: Salemba Medika

Simamora, R. H. (2005). Hubungan Persepsi Perawat Pelaksana Terhadap Penerapan Fungsi Pengorganisasian Yang Dilakukan Oleh Kepala Ruangan Dengan Kinerjanya Diruang Rawat Inap RSUD 
Koja Jakarta Utara (Doctoral dissertation, Tesis FIK UI, Tidak dipublikasikan).

Wijaya, C.P. (2016). PENGARUH BURNOUT SYNDROME TERHADAP PROSES ASUHAN KEPERAWATAN (STUDI PADA PERAWAT RUMAH SAKIT MEDIKA UTAMA BLITAR). JURNAL REVITALISASI Jurnal Ilmu Manajemen. 5(3). 23-36.
Yanti, R.I. Warsito, B.E. (2013). HUBUNGAN KARAKTERISTIK PERAWAT, MOTIVASI, DAN SUPERVISI DENGAN KUALITAS DOKUMENTASI PROSES ASUHAN KEPERAWATAN. Jurnal Managemen Keperawatan. 1(2). 107-114. 